\title{
Impact of Demographic Variables in the Development of Teachers' Self-Efficacy Beliefs in the Context of Saudi Arabia
}

\author{
Mohammed Ali Alwaleedi ${ }^{1}$ \\ ${ }^{1}$ School of Education, University of Queensland, Australia \\ Correspondence: Mohammed Alwaleedi, School of Education, University of Queensland, Australia. Email: \\ google-77@hotmail.com
}

Received: November 18, 2016

Accepted: December 4, 2016

Online Published: December 5, 2016

doi:10.5539/ass.v13n1p1

URL: http://dx.doi.org/10.5539/ass.v13n1p1

\begin{abstract}
Teacher self-efficacy is one of the important variables to bring change in students' learning. The current study aimed to assess teachers' self-efficacy beliefs on four sub-scales; namely, classroom management, persistent behaviour, classroom anxiety and professional mastery, in the context of Saudi Arabia. The key objective of the study was to determine teachers' self-efficacy beliefs on these sub-scales in relation to gender, age, professional qualification, level of teaching, and job experience. A random sample of 168 male and 106 female teachers was selected from two public and two private schools in Jeddah. A Teachers' Self- Efficacy Beliefs scale developed by Shaukat (2011) was administered to collect data from teachers; the results for this study reported .89 overall reliability of the scale, .72 for classroom management, .73 for persistent behaviour, .66 for classroom anxiety and .76 for professional mastery. Data were analysed using the t-test and ANOVA to determine the impact of demographic variables on the four sub-scales of self-efficacy beliefs. Results showed significant differences between the self-efficacy beliefs of male and female teachers; BA, MA and PhD qualified teachers; primary and elementary and secondary school teachers; and public and private teachers with regard to classroom management, persistent behaviour, classroom anxiety and professional mastery. This study has possible implications for policy makers and teacher educators.
\end{abstract}

Keywords: locus of control, persistent behaviour, classroom anxiety, professional mastery, teachers

\section{Introduction}

Teacher self-efficacy is a significant feature of teacher quality that makes a teacher determined to bring about change in students' learning (Pendergast, Garvis, \& Keogh, 2011; Lee, Cawthon, \&Dawson, 2012). Teacher self-efficacy is described as the "teacher's belief in his or her own ability to organise and execute courses of action essential to successfully achieving the specific teaching tasks in specific situations" (Tschannen-Moran, A. Hoy \& W. Hoy, 1998, p. 207). Teachers with a greater level of self-efficacy demonstrate effective teaching strategies to make a difference in students' academic scores and to better assist all students to reach their actual potentials. Teachers with a high sense of self-efficacy tend to apply novel ideas, and are more enthusiastic in trying innovative approaches to make a difference in students' learning (Shaukat \& Iqbal, 2012). Research studies have reported that teacher self-efficacy is connected with teacher determination and perseverance when encountering learning difficulties (Mojavezi \& Tamiz, 2012). Teachers with strong self-efficacy beliefs use more humanistic, constructive and teacher-based approaches to deal with students' problems (Woolfolk, Rosoff, \& Hoy, 1990). Literature has also confirmed that teachers with high levels of self-efficacy tend to apply more individualised instruction and are more likely to use collaborative learning tasks (Tschannen-Moran \& Hoy, 2001). Pertinent international literature self-efficacy reviews are mainly of western origin (Lin \& Gorrell, 2001; Shaukat, 2011), so it is for this purpose that an investigation of teacher self-efficacy beliefs in the context of Saudi Arabia is important. This study will check in a very different cultural context whether there are significant impacts of demographic variables (gender, age, experience and level of teaching) in the development of self-efficacy beliefs of in-service teachers. It is a pioneer research in the Saudi Arabian context which will provide implications for policy leaders and teachers in the adoption of useful strategies to increase self-efficacy beliefs of teachers to make a difference in students' learning. 


\section{Background}

\subsection{Self-efficacy Beliefs}

The self-efficacy construct has generally been hypothesised within Bandura's $(1994,2002)$ social cognitive learning theory. Bandura stated that human behaviour is driven by the interface of two kinds of expectations: self-efficacy expectation and outcome expectancy. The former refers to "peoples' judgments of their capability to undertake and execute successfully a specific task in a specific context, and the latter including judgments about the likely consequences that this performance would bring about" (Mojavezi \& Tamiz, 2012, p. 483). According to Bandura (1977) self-efficacy beliefs are the significant pillars of human action. Self-efficacy beliefs have an impact on an individual's way of thinking, their feeling and their performance in their daily life. They also provide a regulatory principle on how to empower people to exercise some effect over how they are living their lives. These beliefs play a dynamic role in the attainment of knowledge construction on which skills are established and regulate interest for the probable results of one's hard work.

\subsection{Teacher Self-efficacy Beliefs}

The current study pertains to teacher self-efficacy beliefs, defined as teacher's self-confidence in his or her ability/capability to bring about change in students' learning (Bandura, 1995). Ashton and Webb (1986) documented that highly efficacious teachers tend to be more systematised, demonstrate greater skills of instruction, ask probing questions and provide better responses to students having difficulties on academic tasks. Teacher self-efficacy has four sources: mastery experiences, verbal persuasion, vicarious experiences and emotional arousal. The four sources undertake a procedure of cognitive processing that determines how information will be weighted to effect the anticipated teaching task. Mastery experiences are assumed to have the greatest powerful influence as they indicate one's performance in a teaching situation (Mulholland \& Wallace, 2001). Successful performance by an instructor leads to improved self-efficacy, whereas a failure leads to a decrease in self-efficacy beliefs. As teachers tend to develop mastery experience that lead to accruing growth in teacher self-efficacy, they rely on these as memories and explanations of related earlier teaching experiences (Tschannen-Moran, A. Hoy \& W. Hoy, 1998). The second means of increasing self-efficacy beliefs is through the vicarious experiences that are described as observing and perceiving others executing the tasks (Tschannen-Moran, \& Hoy, 2007). This mode of developing self-efficacy allows the acquirement of new actions without practising a trial and error process (Pajares, 2002). Social persuasion is a third source of developing an individual's self-efficacy beliefs. People with substantial persuasive style play a significant role in the development of one's self-efficacy beliefs (Pajares, 2002). Physiological states such as anxiety, strain, and mood also relate to self-efficacy beliefs. Stress and anxiety affect performance such as achievement or failure, and self-efficacy beliefs may be weakened after experiencing and suffering from negative feelings and uncertainties about one's capabilities. These negative perceptions provide the reasons for inadequate performance. Self-efficacy beliefs can be enhanced by reducing the negative physiological states. Individuals have the ability to adopt thinking strategies and self-efficacy beliefs, which in turn can dynamically affect physiological states (Nayak \& Rao, 2000; Pajares, 2002).

\subsection{Dimensions of Teacher Self-efficacy}

Teachers with higher levels of locus of control tend to manage classrooms in more effective ways. Emmer and Hickman (1991) mentioned that classroom management efficacy is a distinct kind of teacher efficacy. In relation to locus of control, efficacy is understood as the degree to which teachers consider that factors under their control have a greater influence on teaching results than do situational factors out of their control (Ajzen \& Madden, 1986). Therefore, specific locus of control research studies can produce items relating to classroom management. Rose and Medway (1981) have suggested the use of the Teacher Locus of Control Scale, which requires teachers to define responsibility for student achievement and failure as within or beyond the control of the teacher.

Teacher persistent behaviour is described by the "tendency to persist steadfastly, until successful, in the many specific courses of action that comprise teaching". A persistent teacher may, for example, attempt many different teaching approaches to present a new concept or skill and persevere with these until the students demonstrate understanding and mastery" (Shaukat, 2011, p. 124). A teacher's belief about determined behaviour may lead to the adoption of a trial-and-error method when confronted with stimulating circumstances until a positive outcome is attained (Pigge \& Marso, 1997). Haberman (1995) has revealed that persistent teaching behaviour is essential for the development of high expectations in students and that it elevates teaching quality. Teacher persistence assists to improve effective teaching, development of teaching skills and efficacy beliefs and openness to students' diversity. 
Teacher anxiety is a significant contributor to personal teaching efficacy. Persons with robust self-efficacy beliefs can employ some control over stressful circumstances. The insight of a lack of control is connected to augmented levels of anxiety (Endler, Speer, Johnson, \& Flett, 2000). It has been found that self-efficacy and test anxiety have a robust negative association (Pintrich \& DeGroot, 1990). Research has revealed that teachers with high levels of nervousness are less verbally helpful to their students and inclined to assign low grades (Clark, 1970). On the other hand, teachers with low nervousness show more promise to accomplish tasks and experience job gratification and better relations with their colleagues. Professional mastery is described as "self-respect through classroom achievement" (Shaukat, 2011, p. 125). Self-respect is assumed to be the degree of the respect a teacher has for his or her own value, reached by self-reflection on previous success with similar classroom activities. By applying extra effort, and with deeper inclination and a robust locus of control, the belief acts as an upsurge in attainment (Schunk, 1982), which results in improved professional self-respect.

Hence, it is crucial to know the self-efficacy beliefs of in-service teachers to match their teaching to the needs of the classroom, and what they have to do to maximise change for the better in a particular teaching situation. As far as Saudi Arabia, and in particular Jeddah, is concerned, the self-efficacy of in-service teachers has rarely been examined. This study will also investigate the impact of demographic variables (gender, age, qualification, experience and teaching levels) in the development of teachers' self-efficacy beliefs in this context. As a result, this study will be able to provide guidelines to policy makers and teaching administrators about what teaching strategies they need to adopt to increase the self-efficacy of teachers.

\section{Research Hypotheses}

This study tests the following hypotheses:

1). There is a significant difference in self-efficacy beliefs of male and female teachers on the four sub-scales: classroom management, persistent behaviour, classroom anxiety and professional mastery.

2). There is a significant difference in self-efficacy beliefs of private and public teachers on the four sub-scales: classroom management, persistent behaviour, classroom anxiety and professional mastery.

3). There is a significant difference in self-efficacy beliefs of BA, MA and $\mathrm{PhD}$ teachers on the four sub-scales: classroom management, persistent behaviour, classroom anxiety and professional mastery

4). There is a significant difference in self-efficacy beliefs of primary, elementary and secondary school teachers on the four sub-scales: classroom management, persistent behaviour, classroom anxiety and professional mastery.

\section{Methodology}

\subsection{Research Design}

This study utilised descriptive research with a questionnaire survey type methodology.

\subsection{Sample}

A simple random sampling technique was used for this study. Sampling was based on school lists in Jeddah. Initially all private and public schools were identified and then a random number table was used to select randomly two schools from each set of public and private schools. The four schools selected have comparable socio-demographic. All selected schools were well reputed as ranked by the Ministry of Education in Saudi Arabia.

\subsection{Participants}

The researcher conducted this study with a sample of 168 male and 106 female teachers. All teachers either had $\mathrm{BA}, \mathrm{MA}$ or Ph.D. degrees and were associated with the four private and public schools. Ages of the teachers ranged from 20 to 60 years. Teachers had working experience ranging from 10 years to 30 years and were teaching at primary, elementary and secondary school levels. See Table 1 for demographic information.

Table 1. Demographic information about participants

\begin{tabular}{cccc}
\hline Variables & & $\mathrm{N}$ & $\%$ \\
\hline \multirow{2}{*}{ Gender } & Male & 168 & 61.3 \\
& Female & 106 & 38.7 \\
Age & $20-30$ & 76 & 27.7 \\
\hline
\end{tabular}




\begin{tabular}{cccc} 
& $30-40$ & 134 & 48.9 \\
& $40-50$ & 56 & 20.4 \\
$50-60$ & 8 & 2.9 \\
\multirow{5}{*}{ Working experience } & 10 years & 64 & 23.4 \\
& 15 years & 83 & 30.3 \\
& 20 years & 54 & 19.7 \\
Level of teaching & 25 years & 42 & 15.0 \\
& 30 years & 32 & 11.7 \\
Nature of school & Primary & 100 & 36.5 \\
& Elementary & 90 & 32.8 \\
Academic qualification & Secondary & 84 & 30.7 \\
& Private & 244 & 89.1 \\
& Public & 30 & 10.9 \\
& Bachelor & 226 & 82.5 \\
& Masters & 42 & 15.3 \\
& PhD & 6 & 2.2
\end{tabular}

\subsection{Instrument}

Demographic Information. Part one of the survey questionnaire required information about the demographic variables of the participants (e.g., gender, age, highest level of qualification, experience in teaching and level of teaching).

Teacher Self-Efficacy Scale. Shaukat, (2011) developed a Likert-type scale to determine teachers' self-efficacy beliefs using a five point response scale to rate each of 24 items ( 1 indicated 'strongly disagree' and 5 indicated 'strongly agree'). The scale used in the earlier research measured the four sub-scales of classroom management, persistent behaviour, classroom anxiety and professional mastery. The original scale statistics for Alpha reliability were: locus of control .72 (6 items), persistent behaviour .73 (7 items), classroom anxiety .56 (4 items) and professional mastery .76 ( 7 items). The overall reliability of the 24 item scale was .89 . Table 2 describes information about the mean, standard deviation and number of items of each of the four sub-scales. (See appendix for scale statements).

Table 2. Reliability of composite scale and sub-scales of Teacher Self-Efficacy

\begin{tabular}{ccccc}
\hline Scale & Mean & Standard Deviation & Number of items & Cronbach Alpha \\
\hline Classroom management & 12.15 & 3.96 & 6 & .72 \\
Persistent behaviour & 14.98 & 4.55 & 7 & .73 \\
Classroom anxiety & 10.98 & 3.18 & 4 & .56 \\
Professional mastery & 15.60 & 4.67 & 7 & .76 \\
Composite scale & 53.72 & 13.51 & 24 & .89 \\
\hline
\end{tabular}

\subsection{Data Collection}

Official permission was received from the authorities concerned with the schools in Jeddah and the nature of the study was discussed with them. After obtaining ethical approval from the school heads, a meeting was arranged between school teachers and the researcher seeking their formal consent to collect the data. The school heads were also informed about the unidentified nature of the survey and were assured that their responses would be kept secret and not shared with anyone. Additionally, they were asked to specify their level of agreement or disagreement with respect to the items selected to determine four of the study's conceptions of self-efficacy (classroom management, persistent behaviour, classroom anxiety and professional mastery). Moreover, 
background information about the respondents, such as gender, age, level of education and teaching and years of experience were also requested. The researcher administered the survey questionnaire using a self-administered approach and data were collected from teachers during their teaching hours in the schools. Incomplete questionnaires were discarded before data entry. Each correspondent took almost 20 to 30 minutes to complete the questionnaire.

\section{Results and Analysis}

In order to determine the male and female teachers' self-efficacy beliefs, a t-test was employed to interpret significant differences on four sub-scales and the composite scale. Similarly the t- test was used to investigate the difference between public and private school teachers. A One-way Analysis of Variance (ANOVA) was also used to measure differences in three qualification groups (BA, MA and $\mathrm{PhD}$ ) and the three levels of teaching (primary, elementary and secondary) with regards to self-efficacy beliefs in terms of locus of control, persistent behaviour, classroom anxiety and professional mastery beliefs.

Table 3. Comparison of means and standard deviation for Teacher Self-Efficacy measures for male and female teachers

\begin{tabular}{cccccccc}
\hline \multirow{2}{*}{ Variables } & \multicolumn{2}{c}{ Male $(\mathrm{n}=168)$} & \multicolumn{2}{c}{ Female $(\mathrm{n}=106)$} & & \multicolumn{2}{c}{ Sig } \\
& $\mathrm{M}$ & $\mathrm{M}$ & $\mathrm{M}$ & $\mathrm{SD}$ & $d f$ & $t$ & $.005^{* *}$ \\
\hline Classroom Management & 16.28 & 10.42 & 20.02 & 10.71 & 272 & -2.86 & $.026^{*}$ \\
Persistent behaviour & 19.24 & 10.65 & 22.06 & 9.41 & 272 & -2.24 & .291 \\
Classroom anxiety & 10.10 & 4.63 & 9.51 & 4.19 & 272 & 1.06 & $.000^{* * *}$ \\
Professional mastery & 19.59 & 10.81 & 25.04 & 11.34 & 272 & -3.99 & .888 \\
Composite scale & 53.63 & 12.95 & 53.87 & 14.40 & 272 & -.14 & \\
\hline
\end{tabular}

$\mathrm{P}<0.00^{* * *}, \mathrm{P}<0.01^{* *}, \mathrm{P}<0.05^{*}$, small effect size

Table 3 shows that there was a statistically significant mean score difference between male and female teachers on the self-efficacy beliefs scale (Hypothesis 1). Females had significantly higher mean scores on the classroom management subscale $(\mathrm{M}=20.02, \mathrm{SD}=10.71)$ than male teachers $(\mathrm{M}=16.28, \mathrm{SD}=10.42)$; $\mathrm{t}(272)=-2.86, \mathrm{p}<$ 0.00 . Likewise, female teachers had significantly greater mean scores on persistent behaviour $(\mathrm{M}=22.06, \mathrm{SD}=$ 9.41) than males $(M=19.24, S D=10.65) ; t(272)=-2.24$. In the same way, female teachers had a significantly higher means score $(M=25.04, \mathrm{SD}=11.34)$ on professional mastery beliefs than male teachers $(\mathrm{M}=19.59, \mathrm{SD}=$ $10.81) ; \mathrm{t}(272)=-3.99$.

Table 4. Comparison of means and standard deviations for Teacher Self-Efficacy measures for private and public school teachers

\begin{tabular}{cccccccc}
\hline \multirow{2}{*}{ Variables } & \multicolumn{2}{c}{ Private $(\mathrm{n}=244)$} & \multicolumn{2}{c}{ Public $(\mathrm{n}=30)$} & & \multirow{2}{*}{ Sig } \\
\cline { 2 - 5 } & $M$ & $S D$ & $M$ & $S D$ & $d f$ & $t$ & \\
\hline Classroom management & 17.32 & 10.28 & 20.96 & 13.16 & 272 & -1.76 & .07 \\
Persistent behaviour & 19.78 & 9.67 & 24.76 & 13.61 & 272 & -2.53 & $.01^{*}$ \\
Classroom anxiety & 10.03 & 4.54 & 8.50 & 3.52 & 272 & 1.78 & .07 \\
Professional mastery & 21.59 & 11.18 & 22.56 & 12.49 & 272 & -.445 & .65 \\
Composite scale & 53.88 & 13.77 & 52.43 & 11.17 & 272 & .553 & .58 \\
\hline
\end{tabular}

$\mathrm{P}<0.05^{*}$, small effect size

Table 4 shows that there was a statistically significant mean score difference between private and public teachers on the self-efficacy beliefs scale (Hypothesis 2). Public school teachers had significantly higher mean scores on the persistent behaviour subscale $(\mathrm{M}=24.76, \mathrm{SD}=13.61)$ than private teachers $(\mathrm{M}=19.78, \mathrm{SD}=9.67) ; \mathrm{t}(272)$ $=-2.53, \mathrm{p}<.01$. 
Table 5. Analysis of variance for the variable of Academic qualification on Teacher Self-Efficacy Scale and its sub-scales

\begin{tabular}{cccccccccc}
\hline Scale & \multicolumn{1}{c}{$\mathrm{BA}(\mathrm{n}=226)$} & \multicolumn{1}{c}{$\mathrm{MA}(\mathrm{n}=42)$} & $\mathrm{PhD}(\mathrm{n}=6)$ & & & \\
\hline & $M$ & $S D$ & $M$ & $S D$ & $M$ & $S D$ & $d f$ & $F$ & Sig \\
Classroom management & 17.34 & 10.53 & 17.85 & 10.41 & 31.33 & 10.15 & 271 & 5.18 & $.00^{* *}$ \\
Persistent behaviour & 19.98 & 10.06 & 20.28 & 10.51 & 33.83 & 7.88 & 271 & 5.49 & $.00^{* *}$ \\
Classroom Anxiety & 7.38 & 4.51 & 7.09 & 3.06 & 7.16 & 3.06 & 271 & 3.48 & .403 \\
Professional Mastery & 21.17 & 10.97 & 22.19 & 11.66 & 38.00 & 11.29 & 271 & 6.78 & $.00^{* *}$ \\
Composite scale & 53.38 & 13.54 & 56.11 & 49.50 & 16.63 & 13.54 & 271 & 1.02 & .36 \\
\hline $\mathrm{P}<0.01^{* *}, \mathrm{P}<0.05^{*}$,
\end{tabular}

$\mathrm{P}<0.01^{* *}, \mathrm{P}<0.05^{*}$, small effect size

Analysis of variance was conducted to test Hypothesis 3: "there is a significant difference in self-efficacy beliefs of $\mathrm{BA}, \mathrm{MA}$ and $\mathrm{PhD}$ teachers on four sub-scales: classroom management, persistent behaviour, classroom anxiety and professional mastery". One way ANOVA results showed significant results among teachers with different qualifications on classroom management, $F(271)=5.18, p<.00$ and persistent behaviour $F,(271)=5.49$, $p<.00$ and professional mastery, $F(271)=6.78, p<.00$.

Table 6. Post hoc Tukey's HSD analysis among BA, MA and PhD qualification on the variable of Teacher Self-Efficacy

\begin{tabular}{ccccc}
\hline ANOVA & & SS & df & MS \\
\hline \multirow{2}{*}{ Classroom management } & Between groups & 1145.22 & 2 & 572.61 \\
& Within groups & 29953.24 & 271 & 110.52 \\
Persistent behaviour & Between groups & 1121.44 & 2 & 560.72 \\
& Within groups & 27639.33 & 271 & 101.99 \\
Classroom anxiety & Between groups & 136.35 & 2 & 68.17 \\
& Within groups & 5304.91 & 271 & 19.57 \\
Professional mastery & Between groups & 1667.11 & 2 & 833.55 \\
& Within groups & 33298.74 & 271 & 122.87 \\
& Between groups & 373.28 & 2 & 186.64 \\
& Within groups & 49411.63 & 271 & 182.33 \\
\hline
\end{tabular}

Post hoc Tukey's HSD was conducted to analyse within-group differences among teachers with BA, MA and $\mathrm{PhD}$ qualifications. Tukey's HSD reflects that teachers with a $\mathrm{PhD}$ qualification had significantly higher classroom management beliefs $(\mathrm{M}=31.33, \mathrm{SD}=10.15)$ than teachers with a $\mathrm{BA}(\mathrm{M}=17.34, \mathrm{SD}=10.53)$ and teachers with a $\mathrm{MA}(\mathrm{M}=17.85, \mathrm{SD}=10.41)$. Similarly, $\mathrm{PhD}$ teachers held significantly greater persistent behaviour beliefs $(\mathrm{M}=33.83, \mathrm{SD}=7.88)$ than teachers with $\mathrm{BA}(\mathrm{M}=19.98, \mathrm{SD}=10.06)$ and $\mathrm{MA}$ qualification $(\mathrm{M}=20.28, \mathrm{SD}=10.51)$. Likewise, $\mathrm{PhD}$. teachers held significantly greater professional mastery beliefs $(\mathrm{M}=38.00, \mathrm{SD}=11.29)$ than $\mathrm{BA}(\mathrm{M}=21.17, \mathrm{SD}=10.97)$ and $\mathrm{MA} .(\mathrm{M}=22.19, \mathrm{SD}=11.66)$ teachers.

Table 7. Analysis of variance for the variable of level of teaching on Teacher Self-Efficacy Scale and its sub-scales

\begin{tabular}{llllllllll}
\hline Scale & Primary $(\mathrm{n}=100)$ & \multicolumn{2}{l}{ Elementary $(\mathrm{n}=90)$} & \multicolumn{2}{l}{ Secondary $(\mathrm{n}=84)$} & & & \\
\hline & $M$ & $S D$ & $M$ & $S D$ & $M$ & $S D$ & $d f$ & $F$ & Sig \\
Classroom management & 20.08 & 12.62 & 15.97 & 8.85 & 16.79 & 9.47 & 271 & 4.04 & $.01^{*}$ \\
Persistent behaviour & 23.26 & 12.67 & 18.15 & 7.44 & 19.17 & 8.87 & 271 & 6.90 & $.00^{* *}$ \\
Classroom Anxiety & 9.53 & 5.33 & 10.04 & 10.08 & 4.27 & 4.51 & 271 & 0.43 & .63 \\
Professional Mastery & 24.10 & 12.91 & 19.43 & 9.31 & 21.26 & 10.79 & 271 & 4.21 & $.01^{*}$ \\
Composite scale & 52.20 & 13.67 & 54.04 & 11.44 & 55.19 & 15.21 & 271 & 1.15 & .31 \\
\hline $\mathrm{P}<0.01^{* *}, \mathrm{P}<0.05^{*}$ & & & & & & & &
\end{tabular}

$\mathrm{P}<0.01^{* *}, \mathrm{P}<0.05^{*}$, small effect size 
Analysis of variance was conducted to test Hypothesis 4 "there is a significant difference in self-efficacy beliefs of primary, elementary and secondary school teachers on four sub-scales: classroom management, persistent behaviour, classroom anxiety and professional mastery". One way ANOVA results showed significant results among teachers with different levels of teaching on classroom management, $F(271)=4.04, p<.01$ and persistent behaviour $F,(271)=6.90, p<.00$ and professional mastery, $F(271)=4.21, p<.01$.

Table 8. Post hoc Tukey's HSD analysis among levels of teaching on the variable of Teacher Self-Efficacy

\begin{tabular}{lllll}
\hline ANOVA & & SS & df & MS \\
\hline Classroom management & Between groups & 901.59 & 2 & 450.79 \\
& Within groups & 30196.87 & 271 & 111.42 \\
Persistent behaviour & Between groups & 1395.39 & 2 & 697.69 \\
& Within groups & 27365.38 & 271 & 100.97 \\
Classroom anxiety & Between groups & 18.12 & 2 & 9.06 \\
& Within groups & 5423.149 & 271 & 20.012 \\
Professional mastery & Between groups & 1054.52 & 2 & 527.26 \\
\multirow{3}{*}{ Composite scale } & Within groups & 33911.33 & 271 & 125.13 \\
& Between groups & 422.14 & 2 & 211.07 \\
& Within groups & 49362.77 & 271 & 182.15 \\
\hline
\end{tabular}

Post hoc Tukey's HSD was conducted to analyse within-group differences among teachers with primary, elementary and secondary teaching levels. Tukey's HSD reflects that teachers who were teaching at a primary level had significantly higher classroom management beliefs $(M=20.08, S D=12.62)$ than $B A(M=15.97$, $\mathrm{SD}=8.85)$ and $\mathrm{MA}(\mathrm{M}=16.79, \mathrm{SD}=9.47)$ school teachers. Similarly, primary teachers held significantly greater persistent behaviour beliefs $(\mathrm{M}=23.26, \mathrm{SD}=12.67)$ than teachers with $\mathrm{BA}(\mathrm{M}=18.15, \mathrm{SD}=7.44)$ and $\mathrm{MA}$ qualifications $(\mathrm{M}=19.17, \mathrm{SD}=8.87)$. Likewise, primary teachers held significantly greater professional mastery beliefs $(\mathrm{M}=24.10, \mathrm{SD}=12.91)$ than $\mathrm{BA}(\mathrm{M}=19.43, \mathrm{SD}=9.31)$ and $\mathrm{MA}(\mathrm{M}=21.26, \mathrm{SD}=10.79)$ teachers.

\section{Discussion}

The current study focused on exploring differences in self-efficacy beliefs of in-service teachers in the context of Saudi Arabia. This research also measured the impact of demographic variables on the development of self-efficacy beliefs of in-service teachers. Teacher gender and teaching level is linked to teachers' job-related beliefs. The main finding of this study was the significant difference between male and female teachers in regard to the classroom management, persistent behaviour and professional mastery beliefs sub-scales. Female teachers demonstrated higher efficacy beliefs on the above mentioned sub-scales. This research finding is consistent with previous research studies (Baldridge, Curtis, Ecker \& Riley, 1978; Halford, 2003; Shaukat, 2011). According to these studies, females tend to demonstrate more patience and tolerance while teaching students in terms of classroom management. They exhibit more persistent behaviour towards students' learning and reveal more self-satisfaction (Shaukat, 2011). In this study, primary school teachers reported higher levels of self-efficacy than teachers at elementary and secondary levels (Wolters \& Daugherty, 2007). Researchers (Anderson, 2011; Karimvand, 2011) reported that female teachers have greater self-efficacy, specifically at the primary level. Another study conducted by Wood (2012) found that female teachers performed better than male teachers while managing their classrooms and they were more inspiring and concerned about their students' classroom needs. Female efficacious teachers not only encourage learning but also stimulate personal development and enthusiasm while providing models of suitable and positive behaviours.

Results from the present study strengthen previous findings that teacher self-efficacy is related with job gratification (Klassen \& Chiu, 2012). In this study, public school teachers held significantly more efficacy beliefs than private school teachers; this finding can be traced to previous research studies (Iqbal, Nageen \& Pell, 2008; Shaukat, 2011). In the context of Saudi Arabia, government school teachers have more job security and access to facilities while teaching students. Public school teachers have handsome salary packages, including transportation allowances, free medical facilities and house rent relief through the government's pay policy. Job security is one of the significant factors which increases self-efficacy beliefs of teachers (Organ \& Lingl, 1995). Due to job security determinants, public school teachers have more job satisfaction and this helps them to keep their morale high in order to make a difference in students' learning. 
The above findings convey significant practical suggestions, particularly for policy makers, that aim to improve teacher education. Teachers with higher levels of self-efficacy beliefs are expected to be more able to generate the circumstances and stimulate the interactive networks that nurture and sustain their work contentment. This study suggests that professional development programs should be designed to match teachers' career stages so that they may improve their professional skills and knowledge, and also increase the self-confidence in their capabilities that teachers at a future career stage possess. Using professional development opportunities to enhance skills and teachers' self-efficacy may lower job anxiety and increase satisfaction from teaching.

\section{Conclusion}

The current study measured and compared the self-efficacy of male and female, private and public, BA, MA and $\mathrm{PhD}$, primary, elementary and secondary teachers on classroom management, persistent behaviour, classroom anxiety and professional mastery sub-scales. It concludes that a, more qualified and experienced female primary teacher is more expected to manage her classroom efficaciously than teachers at the other end of these parameters.

The survey results strengthen the need to place a greater emphasis on self-efficacy development strategies in teachers to prepare students to make a difference in their teaching. The survey results have implications for the research design of future studies. One limitation of this study is that the respondents may not represent a random sample of in-service teachers. Certainly, a larger sample from other cities of Saudi Arabia should be included in the sample for future study. This research also provides a new insight into the design of change in teachers' self-efficacy beliefs. This study was also descriptive in nature and there is still a need to design an experimental study primarily addressing teachers' efficacy belief development.

\section{References}

Ajzen, I., \& Madden, T. J. (1986). Prediction of goal-directed behaviour: Attitudes, intentions, and perceived behavioural control. Journal of Experimental Social Psychology, 22(5), 453-474

Anderson, L. B. (2011). Teacher diversity: Do male and female teachers have different self-efficacy and job satisfaction? Paper Presented in 33rd EGPA Conference, Bucharest, Czechoslovakia.

Ashton, P. T., \& Webb, R. B. (1986). Making a difference: Teachers' sense of efficacy and student achievement. New York: Longman.

Bandura, A. (1995). Self-efficacy in changing societies. Melbourne, Australia: Cambridge University Press.

Bandura, A. (1977). Self efficacy: Toward a unifying theory of behavioral change. Psychological Review, 84(2), 191-215.

Baldridge, J. V., Curtis, D. V., Ecker, G., \& Riley, G. C. (1978). Policy making and effective leadership. San Francisco: Jossey-Bass.

Clark, R. J. (1970). Authoritarianism, educational progressivism and teachers' use of inquiry. (Unpublished doctoral dissertation). Stanford University, Palo Alto, CA.

Emmer, E., \& Hickman, J. (1991). Teacher efficacy in classroom management and discipline. Educational and Psychological Measurement, 51(3), 755-765.

Endler, N. S., Speer, R. L., Johnson, J. M., \& Flett, G. L. (2000). Controllability, coping, efficacy, and distress. European Journal of Personality, 14(3), 245-264.

Haberman, M. (1995). Star teachers of children in poverty. Indianapolis, IN: Kappa Delta PiMoran, M. \& Hoy, A. (2001). Teacher efficacy: capturing an elusive construct. Teaching and Teacher Education, 17, 783-805.

Halford, S. (2003). Gender and organizational restructuring in the National Health Service: Performance, identity and politics. Antipode, 35, 286-308.

Iqbal, H. M., Nageen, T., \& Pell, A. W. (2008). Attitudes to school science held by primary pupils in Pakistan. Evaluation \& Research in Education, 21(4), 269-302.

Karimvand, P. N. (2011). The nexus between Iranian EFL teachers' self-efficacy, teaching experience, and gender. English Language and Teaching, 4(3), 171-183.

Klassen, R. M., \& Chiu, M. M. (2010). Effects on teachers' self-efficacy and job satisfaction: Teacher gender, years of experience, and job stress. Journal of Educational Psychology, 102(3), 741-756.

Mojavezi, A., \& Tamiz, P. M. (2012). The impact of teacher self-efficacy on the students' motivation and achievement. Theory and Practice in Language Studies, 2(3), 483-491. 
Mulholland, J., \& Wallace, J. (2001). Teacher induction and elementary science teaching: Enhancing self-efficacy. Teaching and Teacher Education, 17, 243-261.

Nayak, A. K., \& Rao, V. K. (2002). Educational psychology. New Delhi: A. P. H. Publishing Corporation.

Lee, B., Cawthon, S., \& Dawson, K. (2012). Elementary and secondary teachers' self-efficacy for teaching and pedagogical conceptual change in a drama-based professional development program. Teaching and Teacher Education, 30, 84-98.

Lin, H. L., \& Gorrell, J. (2001). Exploratory analysis of pre-service teacher efficacy in Taiwan. Teaching and Teacher Education, 17(5), 623- 635

Organ, D. W., \& Lingl, A. (1995). Personality, satisfaction and organizational citizenship behavior. The Journal of Social Psychology, 135 (3), 339-350.

Pajares, F. (2002). Overview of social cognitive theory and self-efficacy. Retrieved from, $\mathrm{http}: / /$ www.des.emory.edu/mfp/

Pendergast, D., Garvis, S., \& Keogh, J. (2011). Pre-service student-teacher self-efficacy beliefs: an insight into the making of teachers. Australian Journal of Teacher Education, 36(12), 46-58.

Pigge, R. N., \& Marso, F. L. (1997). A longitudinal study of persisting and non-persisting teachers' academic and personal characteristics. Journal of Experimental Education, 65(3), 243-254.

Pintrich, P. R., \& DeGroot, E. V. (1990). Motivational and self-regulated learning components of classroom academic performance. Journal of Educational Psychology, 82(1), 33-40.

Rose, J. S., \& Medway, F. J. (1981). Measurement of teachers' beliefs in their control over student outcome. Journal of Educational Research, 74 (3), 185-190.

Schunk, D. H. (1982, August). Self-efficacy perspective on achievement behavior (Rep. No. C6016486). Paper presented at the annual convention of the American Psychological Association, Washington, DC. RAND. (ERIC Document Reproduction Service No. ED 226293.).

Shaukat, S., \& Iqbal, M. H. (2012). Teacher self-efficacy as a function of student engagement, instructional strategies and classroom management. Pakistan Journal of Social and clinical Psychology, 10(2), 82-86.

Shaukat, S. (2011). Development and validation of in-service teachers' self-efficacy beliefs in the context of Pakistan. Evaluation and Research in Education, 24(2), 121-141.

Tschannen-Moran, M., \& Hoy, A. W. (2007). The differential antecedents of self-efficacy beliefs of novice and experienced teachers. Teaching and Teacher Education, 23(6), 944-956.

Tschannen-Moran, M., \& Hoy, A. W. (2001). Teacher efficacy: Capturing an elusive construct. Teaching and Teacher Education, 17(7), 783-805.

Tschannen-Moran, M., Hoy, A. W., \& Hoy, W. K. (1998). Teacher efficacy: its meaning and measure. Review of Educational Research, 68, 202-248.

Wood, Y. D. (2012). Teacher perceptions of gender-based differences among elementary school teachers. International Electronic Journal of Elementary Education, 4(2), 317-345

Woolfolk, A. E., Rosoff, B., \& Hoy, W. K. (1990). Teachers' sense of efficacy and their beliefs about managing students. Teaching and Teacher Education, 6, 137-148

Wolters, C. A., \& Daugherty, S. G. (2007). Goal structures and teachers' sense of efficacy: Their relation and association to teaching experience and academic level. Journal of Educational Psychology, 99, 181-193.

\section{Appendix A}

\begin{tabular}{|l|l|l|l|l|l|l|}
\hline $\begin{array}{c}\text { Sr } \\
\text { no }\end{array}$ & \multicolumn{1}{|c|}{ Statements } & $\begin{array}{c}\text { Strongly agree } \\
\text { (5) }\end{array}$ & $\begin{array}{c}\text { Agree } \\
(4)\end{array}$ & $\begin{array}{c}\text { Undecided } \\
\text { (3) }\end{array}$ & $\begin{array}{c}\text { Disagree } \\
(2)\end{array}$ & $\begin{array}{c}\text { Strongly disagree } \\
\text { (1) }\end{array}$ \\
\hline 1 & $\begin{array}{l}\text { I can quickly find out by myself } \\
\text { about all the administrator tasks a } \\
\text { teacher has to do }\end{array}$ & & & & & \\
\hline 2 & $\begin{array}{l}\text { I can know exactly what I am } \\
\text { trying to do in a class }\end{array}$ & & & & & \\
\hline 3 & $\begin{array}{l}\text { I can set myself objectives in class } \\
\text { and then can achieve them }\end{array}$ & & & & & \\
\hline
\end{tabular}




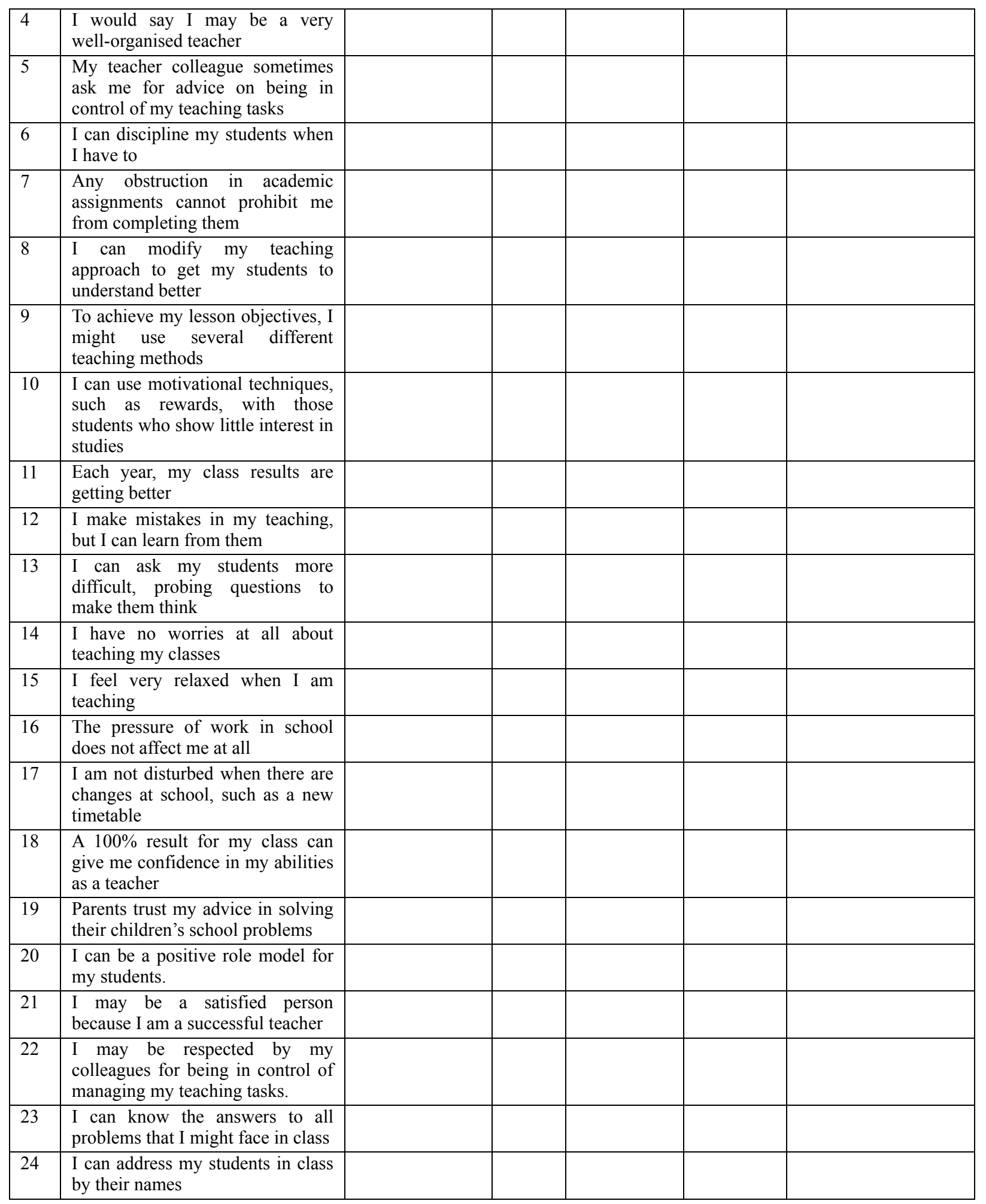

\section{Copyrights}

Copyright for this article is retained by the author(s), with first publication rights granted to the journal.

This is an open-access article distributed under the terms and conditions of the Creative Commons Attribution license (http://creativecommons.org/licenses/by/4.0/). 